Metodički obzori 6(2011)1

Original scientific article

UDK: 373.3 .036

Received: 10. 7. 2010.

\title{
ARTISTIC AND CREATIVE ACHIEVEMENTS OF PRIMARY SCHOOL STUDENTS WITH REGARD TO GENDER AND STRATUM
}

\author{
Jerneja Herzog, PhD student, \\ Faculty of Education Maribor (Slovenia) \\ e-mail: jerneja.herzog@uni-mb.si \\ Matjaž Duh, PhD \\ Faculty of Education Maribor (Slovenia) \\ e-mail: matjaz.duh@uni-mb.si
}

\begin{abstract}
A b stract
The article presents a comparison of artistic and creative achievements of Slovenian fifth grade primary school students using a sample of 321 fifth graders (11 and 12 year olds) from 12 primary schools (4 urban and 8 suburban schools). The previously verified LV1 test was used as the research instrument that was employed to establish the existing condition of artistic creativity. The test was used to monitor six factors of artistic creativity.

The analysis of results indicated that there were statistically significant gender differences in artistic flexibility and sensibility for artistic problems in favour of girls. Furthermore, possible differences among students from the urban and suburban environment were studied. There was a statistically significant difference concerning the factor of artistic fluency, where students from the urban environment achieved better results.
\end{abstract}

Keywords: creativity, artistic creativity, factors of artistic creativity, primary school

\section{Introduction}

Creativity is increasingly gaining in importance. Professionals from all fields are becoming aware of its importance for the development of creative and critical thinking. In education, definitions vary from completely new ideas to new ways of considering and solving problems, from creativity specific to the arts to the idea of scientific breakthrough. According to Csikszentmihalyi (1996), most commercial programmes aimed at increasing individual creativity focus on divergent thinking which is considered important to creativity fluency and originality (relative rarity of an idea). The importance of creativity was further pointed out in the UK by the National Advisory Committee on Creative and Cultural Education (NACCCE: 
1999) that, based on research conducted in an early years school, distinguished between teaching creatively and teaching for creativity. It is common knowledge that artistic creativity is in high correlation with general creativity or that the development of artistic creativity has a positive effect on the development of general creativity. Art education should be based on developing creativity. A teacher should employ appropriate teaching methods and creative tasks to facilitate creative games and consequently creative thinking in students.

There have been numerous interesting studies made on creativity (see: Chan, W. D., Chan, L. 2007, p. 77-95) including the impact that individual artistic techniques have on the development of creativity. According to Dinkelmann (2008), the school environment is the one that offers the largest number of possibilities to facilitate artistic creativity. He adds that the latter is realised in actions and thinking and can as such arise from studying artistic material or independent games of mental skill using associations. Creativity in design and technology means seeing possibilities, problems and challenges and visualising alternatives to develop innovative products and processes. It involves exploring and experimenting with ideas, materials, technologies and techniques. In art and design creativity is producing imaginative images, artefacts and other outcomes that are both original and of value. "Pupils show creativity when they play with ideas and generate different approaches, responding to purposeful tasks in imaginative and personal ways to produce original images and artefacts." (Rutland, 2009, p. 58). However, there is another important factor in the development of creativity that should not be neglected, i.e. the family. The family provides the child with security and enables him to learn different skills that he needs in life. Across the spectrum of all functions that it holds towards the child, it also has an important effect on the child's creative behaviour (Dacey, 1989; as quoted by Kemple K. and Nissenberg S., 2000, p. 6771). Wright and Wright have developed a three-pronged model of the creative family environment. The three main components of the creative family environment are said to be: respect for the child, stimulation of independence and an enriched learning environment. They believe a creative family environment needs to show respect for the child, consult with him and explain its choices to him. Creative children often come from families where the parents explain the family's decisions and rules and where the rules are co-shaped by the children themselves. A creative family environment facilitates independence by providing freedom and psychological safety in exploring, experimenting and decision making (Baldwin, 1949; MacKinnon, 1961; quote ibid).

In order to enhance the quality of the child's development, parents should be actively included in the formal educational process and realise the common goals together with teachers. Teachers should advise parents on interesting ways to enhance the creative spirit at home, raise their interest in creative games, provide them with information on the creative family model and characteristics of creativity and inform parents about the dangers that may threaten the child's development. On the other hand, parents themselves have numerous ideas on how to spark the creative imagination and facilitate creative thinking (Kemple and Nissenberg, 2000, p. 6771). The potential differences of the interpretation of creativity in different subjects 
is illustrated by the following thinking (Rutland and Barlex, 2002; Barlex 2003a). The performing arts are a highly educating experience where each actor can bring a level of personal interpretation to their roles depending on the openness of the director of the performance. "But is this creativity different from the creativity of visual artists who conceive the new in the mind's eye and transform this concept into a physical reality by making pieces of art?" (Rutland, 2009, str. 59). According to Žagar, creativity requires additional skills and personal characteristics with the most important ones being intelligence, divergent thinking, curiosity and nonconformism. (Žagar, 1992, p. 12). The behaviourist tradition explains creativity as the response of an individual to influences in the environment. As Craft (2001) notes, "Implicit within behaviourist programmes is the assumption that creativity is learned and that it can be fostered through stimulus, reinforcement and response". Although Eysenck was a behaviourist, his IQ test principles have been extensively used in the testing of creativity. He identified links between his psychoticism scale and degrees of creativity, noting that there were both an accepted relationship and a difference between genius and madness (Eysenck: 1993).

Different studies (Barron 1957; Getzels and Jakson 1962; Yamamoto 1964; Flescher 1963, quote by Duh 2004) that searched for a correlation between intelligence and creativity indicated that all combinations were possible between intelligence and creativity, which corresponded to Hitt's results (1965) that there existed combinations of logical (convergent) and original (divergent) thinking. The mentioned studies allowed psychologists to establish that a high level of intelligence is necessary for creativity. (Duh, 2004 p. 16-17). The correlation between intelligence and creativity is small and is not linear. Another important finding is that not the same level of intelligence is required for all areas of creativity. For the needs of this research only the area of artistic creativity was explored. One of such areas of artistic creativity is the creativity specific to visual arts. "It can also be defined as artistic creativity with added specific visual arts elements that are the means of expression of visual arts. An artwork is multilayered and carries more than one meaning, which is evident from its complex process of development (Duh, 2004, p. 22). The current findings allow us to classify six factors of artistic creativity into two groups and to form three pairs of factors that complement each other. Duh (2004). Redefinition, fluency and elaboration enable creativity, which however does not mean that this group does not display facilitating characteristics. It does, but to a smaller extent. Originality, flexibility and sensibility for problems facilitate creativity, as it is their leading component. To a smaller degree, they also include elements that enable creativity.

The process of redefinition enables creativity, which means that existing objects are used in a new way. The redefinition factor is paired with originality that facilitates creativity and results in new creative artistic solutions. Fluency is the ability to produce a large number of artistic ideas, forms, hues and technical versions and is as such part of the group of factors enabling creativity, as it provides the requisite material for creative work. Fluency is paired with flexibility and understood as the search for different ways or solutions to a given problem. Flexibility is the ability to facilitate and with the given material it ensures a creative 
approach. The last pair are the factors of elaboration and sensibility for artistic problems. Elaboration, which enables creativity, is evident as the effort in organising the creative process. Sensibility for artistic problems facilitates creativity, as the artistic experience involves emotional components (Duh, 2004, p. 29).

\section{Content of the research}

The research studied the actual situation of artistic and creative abilities of 11 and 12-year olds. The level of artistic creativity was established by monitoring the six factors of creativity, with three of these factors facilitating creativity (originality, flexibility and sensibility for artistic problems) and three enabling it (artistic redefinition, fluency and elaboration). Each of these factors was monitored through special tasks in the test and the students' solutions were assessed using a prepared scale.

\section{Methodology of the research}

\section{Research method}

The research was conducted using the causal and non-experimental method of educational research.

\section{Research sample}

The research sample comprised 321 fifth-grade students (11 and 12-year olds) from 12 Slovenian primary schools (4 urban and 8 suburban schools).

\section{Process of data collection}

The test was conducted in one school period. The test conditions for solving the LV1 test were the same for all students.

\section{Description of measurement instruments}

The proven LV1 (Duh, 2004) test was used, which yielded sufficiently reliable results in similar conditions of educational research. All tested students received the same instructions and were given the same time to solve the six tasks that required independent drawing and adding. The tasks monitored the factors of artistic creativity, which enabled us to measure the level of artistic creativity. The LV1 test monitored the factors of artistic creativity, i.e. artistic flexibility, fluency, originality, redefinition, sensibility for artistic problems and elaboration. 


\section{Data processing}

The test tasks were evaluated and data were processed on the descriptive level and on the level of interference statistics. The obtained data were processed using the SPSS software.

\section{Research hypotheses}

The results were interpreted in two sets. First, the level of artistic and creative abilities between boys and girls was compared and then between students from the urban and suburban environment.

Two sets of hypotheses were defined:

Gender related hypotheses:

$\mathrm{H}_{\mathrm{GD}}$ 1: The level of achieved results in the factor of artistic flexibility that facilitates creativity does not differ by gender.

$\mathrm{H}_{\mathrm{GD}}$ 2: The level of achieved results in the factor of artistic fluency that enables creativity does not differ by gender.

$\mathrm{H}_{\mathrm{GD}} 3$ : The level of achieved results in the factor of originality that facilitates creativity does not differ by gender.

$\mathrm{H}_{\mathrm{GD}} 4$ : The level of achieved results in the factor of artistic redefinition that enables creativity does not differ by gender.

$\mathrm{H}_{\mathrm{GD}}$ 5: The level of achieved results in the factor of sensibility for artistic problems that facilitates creativity does not differ by gender.

$\mathrm{H}_{\mathrm{GD}} 6$ : The level of achieved results in the factor of elaboration that enables creativity does not differ by gender.

Stratum related hypotheses:

$\mathrm{H}_{\text {STR }}$ 1: The level of achieved results in the factor of elaboration that enables creativity does not differ by stratum.

$\mathrm{H}_{\mathrm{STR}} 2$ : The level of achieved results in the factor of artistic flexibility that facilitates creativity does not differ by stratum.

$\mathrm{H}_{\mathrm{STR}} 3$ : The level of achieved results in the factor of artistic fluency that enables creativity does not differ by stratum.

$\mathrm{H}_{\mathrm{STR}} 4$ : The level of achieved results in the factor of originality that facilitates creativity does not differ by stratum.

$\mathrm{H}_{\text {STR }}$ 5: The level of achieved results in the factor of artistic redefinition that enables creativity does not differ by stratum.

$\mathrm{H}_{\mathrm{STR}}$ 6: The level of achieved results in the factor of sensibility for artistic problems that facilitates creativity does not differ by stratum. 


\section{Results and discussion}

The interpretation of the results was divided into two parts. In the first part the level of artistic and creative abilities was compared with regard to gender and in the second part the level of artistic and creative abilities was compared with regard to urban and suburban stratum of primary schools attended by the tested students.

\section{Results analysis by gender}

A comparison of the level of artistic and creative abilities by gender yielded interesting results that are depicted in the table below.

Table 1: Results of the T-test of differences between arithmetic means and the F-test of the equality of variances by gender in factors of artistic creativity

\begin{tabular}{|c|c|c|c|c|c|c|c|c|c|}
\hline \multirow{2}{*}{ 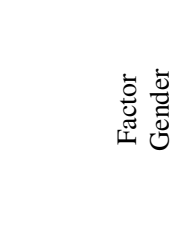 } & & \multirow{2}{*}{ 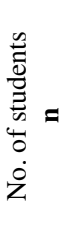 } & \multirow{2}{*}{ 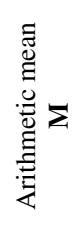 } & \multirow{2}{*}{ 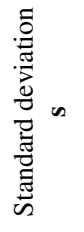 } & \multicolumn{2}{|c|}{$\begin{array}{c}\text { Levene's } \\
\text { equality of } \\
\text { variances test }\end{array}$} & \multicolumn{3}{|c|}{$T$-test } \\
\hline & & & & & $\mathbf{F}$ & $\mathbf{P}$ & $\mathbf{T}$ & g & $\mathbf{P}$ \\
\hline \multirow{2}{*}{ Flexibility } & $\mathrm{M}$ & 164 & 2.561 & 1.666 & \multirow{2}{*}{1.605} & \multirow{2}{*}{0.206} & \multirow{2}{*}{-3.671} & \multirow{2}{*}{318.591} & \multirow{2}{*}{0.000} \\
\hline & $\mathrm{F}$ & 157 & 3.217 & 1.533 & & & & & \\
\hline \multirow{2}{*}{ Fluency } & $\mathrm{M}$ & 164 & 3.598 & 1.186 & \multirow{2}{*}{0.131} & \multirow{2}{*}{0.717} & \multirow{2}{*}{-1.392} & \multirow{2}{*}{317.873} & \multirow{2}{*}{0.165} \\
\hline & $\mathrm{F}$ & 157 & 3.783 & 1.205 & & & & & \\
\hline \multirow{2}{*}{ Originality } & $\mathrm{M}$ & 164 & 1.256 & 0.904 & \multirow{2}{*}{0.436} & \multirow{2}{*}{0.510} & \multirow{2}{*}{-0.498} & \multirow{2}{*}{318.887} & \multirow{2}{*}{0.619} \\
\hline & $\mathrm{F}$ & 157 & 1.305 & 0.882 & & & & & \\
\hline \multirow{2}{*}{ Redefinition } & $\mathrm{M}$ & 164 & 2.921 & 1.837 & \multirow{2}{*}{0.022} & \multirow{2}{*}{0.882} & \multirow{2}{*}{-0.044} & \multirow{2}{*}{317.767} & \multirow{2}{*}{0.965} \\
\hline & $\mathrm{F}$ & 157 & 2.930 & 1.871 & & & & & \\
\hline \multirow{2}{*}{$\begin{array}{l}\text { Sensibility for } \\
\text { art. problems }\end{array}$} & $\mathrm{M}$ & 164 & 3.305 & 1.580 & \multirow{2}{*}{1.714} & \multirow{2}{*}{0.191} & \multirow{2}{*}{-3.198} & \multirow{2}{*}{317.782} & \multirow{2}{*}{0.002} \\
\hline & $\mathrm{F}$ & 157 & 3.841 & 1.421 & & & & & \\
\hline \multirow{2}{*}{ Elaboration } & $\mathrm{M}$ & 164 & 3.537 & 1.540 & 0.016 & 0.900 & -1.457 & 318939 & 0146 \\
\hline & $\mathrm{F}$ & 157 & 3.783 & 1.495 & & & & & \\
\hline
\end{tabular}

The interpretation of the achieved results in monitoring factors of artistic creativity of boys and girls indicates that girls achieved much higher values in two of the tasks or in two factors of artistic creativity. The T-test revealed statistically significant differences in favour of girls in artistic flexibility $(\mathrm{P}=0.002)$, which contradicts the $\mathrm{H}_{\mathrm{GD}} 1$ and $\mathrm{H}_{\mathrm{GD}} 5$ hypotheses, where it was assumed that gender does not influence the level of achieved results in the factors of flexibility and sensibility for artistic problems. All other hypotheses were confirmed by both tests. The obtained results show that girls display better skills in two of the three factors that facilitate creativity. It can be noted that girls were more successful in adapting visual means of expression, recognising artistic problems and in searching for different and more sensible artistic solutions. It is interesting to compare these results with the results of another study that also monitored the level of artistic creativity in eleven 
and twelve-year olds but used the LV2 test. (Herzog, 2008). Despite different tests, the results of both studies show a remarkable similarity of final results. Both studies confirm the statistically significant difference in favour of girls in the factor of artistic flexibility (the LV2 test: $\mathrm{P}=0.016$, the $\mathrm{LV} 1$ test: $\mathrm{P}=0.000$ ) and sensibility for artistic problems (the $\mathrm{LV} 2$ test: $\mathrm{P}=0.001$, the $\mathrm{LV} 1$ test: $\mathrm{P}=0.002$ ). The only exception is the factor of elaboration, where in the LV2 test, the F-test noted statistically significant differences in favour of girls $(\mathrm{P}=0.030)$, while the study conducted using the LV1 test did not statistically confirm these differences.

\section{Results analysis by stratum}

Table 2: Results of the T-test of differences between arithmetic means and the F-test of the equality of variances by stratum in factors of artistic creativity

\begin{tabular}{|c|c|c|c|c|c|c|c|c|c|}
\hline \multirow[t]{2}{*}{ 节 } & \multirow[t]{2}{*}{ 壳 } & \multirow{2}{*}{ 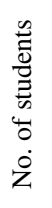 } & \multirow{2}{*}{ 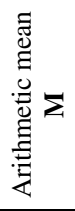 } & \multirow{2}{*}{ 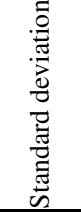 } & \multicolumn{2}{|c|}{$\begin{array}{c}\text { Levene's } \\
\text { equality of } \\
\text { variances test }\end{array}$} & \multicolumn{3}{|c|}{$T$-test } \\
\hline & & & & & $\mathbf{F}$ & $\mathbf{P}$ & $\mathbf{T}$ & g & $\mathbf{P}$ \\
\hline \multirow{2}{*}{ Flexibility } & urban & 124 & 2.936 & 1.642 & \multirow{2}{*}{0.071} & \multirow{2}{*}{0.790} & \multirow{2}{*}{0.468} & \multirow{2}{*}{260.279} & \multirow{2}{*}{0.640} \\
\hline & suburban & 197 & 2.848 & 1.631 & & & & & \\
\hline \multirow{2}{*}{ Fluency } & urban & 124 & 3.895 & 1.050 & \multirow{2}{*}{10.518} & \multirow{2}{*}{0.001} & \multirow{2}{*}{2.580} & \multirow{2}{*}{295.802} & \multirow{2}{*}{0.010} \\
\hline & suburban & 197 & 3.558 & 1.267 & & & & & \\
\hline \multirow{2}{*}{ Originality } & urban & 124 & 1.266 & 0.866 & \multirow{2}{*}{0.918} & \multirow{2}{*}{0.339} & \multirow{2}{*}{-0.230} & \multirow{2}{*}{274.598} & \multirow{2}{*}{0.821} \\
\hline & suburban & 197 & 1.289 & 0.916 & & & & & \\
\hline \multirow{2}{*}{ Redefinition } & urban & 124 & 2.960 & 1.805 & \multirow{2}{*}{1.247} & \multirow{2}{*}{0.265} & \multirow{2}{*}{0.267} & \multirow{2}{*}{269.801} & \multirow{2}{*}{0.790} \\
\hline & suburban & 197 & 2.904 & 1.883 & & & & & \\
\hline \multirow{2}{*}{$\begin{array}{l}\text { Sensibility for } \\
\text { art. problems }\end{array}$} & urban & 124 & 3.774 & 1.524 & \multirow{2}{*}{0.002} & \multirow{2}{*}{0.964} & \multirow{2}{*}{1.937} & \multirow{2}{*}{260.514} & \multirow{2}{*}{0.054} \\
\hline & suburban & 197 & 3.437 & 1.516 & & & & & \\
\hline Elaboration & urban & 124 & 3.589 & 1.706 & 8756 & 0.003 & -0.612 & 223.448 & 0.541 \\
\hline 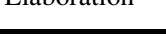 & suburban & 197 & 4.701 & 1.395 & & & & & \\
\hline
\end{tabular}

The results of the sample of students and both of the above-mentioned studies allow us to conclude that girls are more sensitive in their perceptions, more accurate and better skilled in discovering new paths in searching for artistic solutions. However, it should not be neglected that the difference in the stated factors might be the result of physiological differences. It was observed during practical implementation that girls are in general quieter and more concentrated in following the instructions than the boys and have therefore achieved much better results in factors where accuracy and sensibility are of priority. The statistical research however does not cover all these observations in its results and it is therefore important to be aware that, despite these results, boys are not less capable but mainly more energetic than girls and are as such less concentrated when following instructions.

It is a well known fact that the environment in which we live has an important impact on human development, which allows us to deduct that it also affects the artistic and creative development of students. The present study established whether 
there were any differences in the level of achieved results with regard to whether students live and attend schools in cities or in the suburbs.

In monitoring the artistic factors with regard to the stratum, five hypotheses were confirmed and one disproved $\left(\mathrm{H}_{\mathrm{STR}} 3\right)$, because statistically significant differences were noted in the artistic fluency factor, i.e. a factor that enables artistic creativity. It has been established that the sample of students from the urban environment achieved higher values in the artistic fluency factor than students from the suburban environment. The statistical difference $(\mathrm{P}=0.010)$ in favour of students from the urban environment was surprising, as it was not expected that stratum would affect results of factors of artistic creativity. The reasons can be traced to better access to different didactic aids as well as to better computer competence, knowledge of games and similar present in the urban environment. The instructions for the test task that monitored artistic fluency were faster and better understood by children from the urban environment than by the children from the suburban environment, who had more problems with this task. Even though the same instructions were given in all schools, in suburban schools these instructions were supported with additional explanations but test results were nevertheless worse. Other hypotheses were also confirmed. The findings of this study point to the important fact that in order for educational work to be successful and of a high quality resulting in creative joy, teachers require a lot of appropriate knowledge. Results confirmed that both boys and girls, regardless of stratum, achieve very low results in creative factors that require innovative ideas, new ways to problem solving, the transformation of new into something known, etc. Judging from the sample of fifth-grade students, it seems that they have difficulties surpassing the framework of the learned thinking and have problems settling into new situations. Therefore, their solutions, especially as regards factors of artistic originality and redefinition, are mostly monotonous and less creative, which is evident from the average values of achieved results.

The study further compared the possible role of gender and stratum in the achieved levels of artistic and creative skills. In accordance with the expectations and previous studies (Herzog, 2008), it has been confirmed that, with regard to artistic flexibility and sensibility for artistic problems, girls achieve better results than boys. Despite statistically significant differences in favour of the girls in two of the factors, it should not be disregarded that girls are in general quieter and more attentive when listening to instructions than their livelier peers. We were however surprised by the results regarding the role of urban and suburban environment from the viewpoint of factors of artistic creativity. Students from the urban environment achieved better results in the factor of artistic fluency, where different versions, skills and a wealth of ideas play an important role. It is assumed that the reason for such results lies in the easier and more diverse access to didactic means, computers, the Internet, games and other aids. It has therefore been confirmed that a rich learning environment is of exceptional importance to the comprehensive development of children. 


\section{Conclusion}

It would be interesting to compare the results of this study, which focused exclusively on the area of the Maribor Region, with similar studies conducted in other regions within and outside Slovenia and to search for possible similarities and differences. A similar research into art and creativity that was conducted among fifth-grade students could be implemented in lower and higher grades. In this way, it would be possible to compare not only the creative achievements of same age students but throughout the entire process of primary school education. "An issue often raised amongst Creative Arts education professionals and researchers at an international level is whether generalist primary teachers with no specialist Arts knowledge are capable of realising the learning potential of the Creative Arts in schools (Alexander, Rose, \& Woodhead, 1992; Eisner, 1994; La Pierre \& Zimmerman, 1997; Welch, 1995). Generalist teachers are often perceived as lacking the requisite experience and training to teach the Creative Arts effectively. Holt's (1997) study of art education in the United Kingdom found that primary education falls below what can be considered 'satisfactory' performance in over one third of schools studied. He notes that most generalists are hard working but have limited understanding of materials and a lack of knowledge about art. He further attributes this to the way that primary teachers have been trained". (Alter, Hays, O'Hara, 2009, p. 3). There is a meaningful flower simile that can be applied to creativity: "... we can influence it by watering, fertilizing and weeding it and providing it with light and the best conditions for growth. However, the flower grows on its own. We cannot order it to grow and even less so to change its blossom." (Pečjak, 1987, p. 9).

\section{References}

Alexander, R., Rose, J., \& Woodhead, C. (1992). Curriculum organisation and classroom practice. London: HMSO.

Alter,F., Hays,T., O’Hara, R.(2009). Creative Arts Teaching and Practice: Critical Reflection of Primary School Teachers in Australia. International Journal of Education \& the Arts, 10(9). Retrieved [31.12.2010] from http://www.ijea.org/v10n9/.

Alenizi, M. (2008). Assessment of Creativity in Education. Retrieved [31.12.2010] from http://www.eric.ed.gov/PDFS/ED505220.pdf

Alter, F., Hays, T., \& O'Hara, R. (2009). Creative arts teaching and practice: Critical reflections of primary school teachers in Australia. International Journal of Education \& the Arts, 10(9). Retrieved [31.12.2010] from http://www.ijea.org/v10n9/.

Barlex, D (2003a) 'Creativity in Art and Design and Design and Technology in the National Curriculum' An Exploration commissioned by the Qualifications and Curriculum Authority (QCA): London.

Chan, D. W., Chan, L. (2007). Creativity and Drawing Abilities of Chinese Students in Hong Kong: Is There a Connection? New Horizons in Education, 55 (3), pp 77-95. 
Craft, A. (2001) An analysis of research and literature on creativity in education report prepared for QCA online at http://www.ncaction.org.uk/creativity/creativity_report.pdf [accessed 29.12.2010]

Csikszentmihalyi, M. (1996) Creativity: Flow and the Psychology of Discovery and Invention New York, Harper Collins

Dinkelmann, K. (2008). Kreativitätsförderung im Kunstunterricht. München: Herbert Utz Verlag.

Duh, M. (2004). Vrednotenje kot didaktični problem pri likovni vzgoji. Maribor: Pedagoška fakulteta.

Eisner, E. (1994). The educational imagination: On the design and evaluation of school programs (3rd edition). New York: Macmillan.

Eysenck, H. J. (1993) Creativity and personality: Suggestions for a theory. Psychological Inquiry, 4, 147-178 Psychology Press

Herzog, J. (2008). Porazdelitev likovnoustvarjalnih sposobnosti med osnovnošolci. Revija za elementarno izobraževanje 1 (3-4), str. 87-94.

Herzog, J. (2009). Dejavniki likovne ustvarjalnosti in likovnopedagoško delo. Revija za elementarno izobraževanja, 2 (2-3), str. 19-31.

Holt, D. (Ed.). (1997). Primary arts education: Contemporary issues. London: Falmer Press.

Jurman, B. (2004). Inteligentnost, ustvarjalnost, nadarjenost. Ljubljana: Center za psihologijo.

Kemple K., Nissenberg S. (2000). Nurturing creativity in early childhood education: families are part of it. Early Childhood Education Journal, 28 (1), 67-71.

La Pierre, S., \& Zimmerman, E. (1997). Research methods and methodologies in art education. Reston, VA: National Art Education Association.

Myers K., Warner S. (2010).The creative classroom: the role of space and place toward facilitating creativity. The Technology Tacher, 28-34. Our Futures:

National Advisory Committee on Creative and Cultural Education (NACCCE) (1999) All

Creativity, Culture and Education, London: Department for Education and Employment

Rockness, M. (1983). A time to play: reflections on childhood and creativity. Retrieved [8.8.2010] from

http://books.google.com/books?id=9d0OAAAAQAAJ\&pg=PA14\&lpg=PA14\&dq=miriam+rockn ess+childhood+is+the+morning+time+of+creativity\&source $=$ bl\&ots $=$ C_VpGv1ZJ6\&sig $=S$ V cruL BhFrSdg4Mg0b99sG3jvvs\&hl=en\&ei=13qHTMTLOMWAswbUsdDFCg\&sa=X\&oi=book_result \&ct=result\&resnum $=1 \& v e d=0$ CBIQ6AEwAA\#v=onepage \&q \&f=false

Rutland, M. and Barlex, D. (2002) 'The relationship between art and design and design and technology in the English curriculum with reference to creativity', in Technology Education in the Curriculum: Relationships with Other Subjects, PATT-12 International Conference, Columbus, OHIO, USA www.iteaconnect.org/PATT12/rutland.pdf

Rutland, M. (2009). Art and Design and Technology: Is there creativity in the designing? Design and Technology Education, Vol 14, No 1, (2009), 56-67.

Welch, A. (1995). The self-efficacy of primary teachers in art education, Issues in Educational Research, 5, 71-84.

Žagar, D. (1992). Razvijanje ustvarjalnosti učencev. Ljubljana: Slovensko društvo pedagogov. 
Metodički obzori 6(2011)1

Izvorni znanstveni rad

UDK: 373.3 .036

Primljeno: 10. 7. 2010.

\title{
LIKOVNO-USTVARJALNI DOSEŽKI UČENCEV V OSNOVNI ŠOLI Z VIDIKA SPOLA IN STRATUMA
}

\author{
Assist. Jerneja Herzog, prof. (doktorant), \\ Pedagoški fakultet, \\ Sveučilište u Mariboru (Slovenija) \\ e-mail: jerneja.herzog@uni-mb.si
}

Doc. dr. Matjaž Duh, Pedagoški fakultet, Sveučilište u Mariboru (Slovenija) e-mail: matjaz.duh@uni-mb.si

\section{Povzetek}

$\mathrm{V}$ prispevku predstavljamo primerjavo likovno-ustvarjalnih dosežkov pri učencih petega razreda slovenskih osnovnih šol, na vzorcu 321 petošolcev (11- in 12-letnikov) iz 12 osnovnih šol (4 mestne in 8 primestnih šol). Kot instrument raziskovanja za ugotavljanje obstoječega stanja likovne ustvarjalnosti je bil uporabljen že preverjen test LV1. S testom je bilo spremljanih šest dejavnikov likovne ustvarjalnosti.

Analiza rezultatov je pokazala, da med spoloma obstajajo statistično značilne razlike pri dejavniku likovne fleksibilnosti in občutljivosti za likovne probleme $\mathrm{v}$ prid deklicam. Prav tako so bile raziskane morebitne razlike med učenci iz mestnega oz. primestnega okolja. Statistično značilna razlika je bila zaznana pri dejavniku likovne fluentnosti, kjer so dosegli boljše rezultate učenci iz mestnega okolja.

Ključne besede: ustvarjalnost, likovna ustvarjalnost, dejavniki likovne ustvarjalnosti, osnovna šola

\section{LIKOVNO KREATIVNA POSTIGNUĆA UČENIKA OSNOVNE ŠKOLE SA ASPEKTA SPOLA I STRATUMA}

\section{Sa žetak}

U prilogu predstavljamo usporedbu likovno kreativnih postignuća kod učenika petih razreda u slovenskim osnovnim školama, na uzorku 321 petoškolaca (11 i 12 godišnjaka) iz 12 osnovnih škola (4 gradske i 8 prigradskih škola). Kao istraživački instrument za praćenje aktualnog stanja likovne kreativnosti upotrijebili smo već provjereni test LV1. Sa testom smo pratili šest faktora likovne kreativnosti.

Analiza rezultata ukazala je na postojeću statistički značajnu razliku kod faktora likovne fleksibilnosti i osjetljivosti za likovne probleme u korist djevojčica. Isto tako su bile istraživane moguće razlike između učenika iz gradskog i 
prigradskog okoliša. Statistički značajna razlika zapažena je kod faktora likovne fluentnosti, gdje su olje rezultate postigli učenici iz gradskog okoliša.

Ključne riječi: kreativnost, likovna kreativnost, faktor likovne fluentnosti, osnovna škola 